\title{
Quality of orthophoto mosaics made with different methods
}

\author{
Natalja Liba, \\ Ina Järve, \\ Marian Rand \\ Estonian University of Life Sciences, \\ Kreutzwaldi 5, 51014 Tartu, Estonia \\ E-mail: natalja.liba@emu.ee; \\ ina.jarve@emu.ee
}

\begin{abstract}
The photogrammetric products, especially orthophotos, have become an important part of spatial databases, considering the modern technical development. The demand for more detailed photos and better resolutions is growing, which gives rise to the demand for photos with higher precision available as quickly as possible. Photogrammetric software used for producing ortophotos enables making some phases of orthophotos automatically. But every phase affects the quality of the final product. The question arises - How much can we use the automatic steps of the software for creating digital orthophotos if we want to keep the quality that is requested by users?

For the answer of the before-mentioned question 4 orthophoto mosaics were made differing by their processing method, i. e. automated or manual processing. For that photographs made by a digital frame aerial camera UltraCam D were used as well as the photogrammetric software Photomod version 5.1 made in Russia. For the analysis the geometrical quality of each mosaic was investigated by ground control points measured in nature and on the mosaics. The accuracy is given by RMS not bigger than 0.45 meters. Three orthophoto mosaics were according to the given precision. The most geometrically accurate mosaic's RMS was $0.308 \mathrm{~m}$ which is calculated in turn with the error $0.069 \mathrm{~m}$ in the manual project. Only the mosaic of the full-automatic project was not in the permitted size, the RMS was $1.805 \mathrm{~m}$.
\end{abstract}

Key words: aerial triangulation, digital elevation model (DEM), geometrical quality, GSD, orthophoto mosaic, UltraCam D

\section{INTRODUCTION}

Rapid development of technology in the field of photogrammetry, especially the coming of digital aerial cameras on the market, has increased the usage of digital photo products. Photogrammetrical softwares nowadays make it possible to quickly produce large area photo products, the biggest value of which is the 3-dimensional high precision and high resolution information. The sources, which are used, also have very different resolutions and quality, depending on the client's demands.

In the Department of Geomatics of the Estonian University of Life Sciences, several researches for master thesis have been carried out on photos of a frame camera, taken with an analog camera
RC30 (2005 - Ina Järve: "Making orthophotomosaic about Tartu City with Photomod program and its geometrical quality"; 2010 - Tatjana Abdurahmanova: "Control of the geometric accuracy of mosaics produced using various principles of triangulation"), and later already on digital images taken with a pushbroom line scanner ADS40 (2011 - Jaana Šeffer: "Creation of digital stereo models and orthomosaic from pushbroom images and their geometrical quality"). The current research examines the effect of automated processing steps on the accuracy of orthophoto mosaics by geometrical quality. Due to the lack of studies supported on the camera and images with to $80 \%$ alongside overlapping, then digital images of UltraCam D were used. Photomod version 5.1. was 
used for processing images and making mosaics with different methods. Photomod differs from other systems by that the software enables to make orthophotos from the beginning to the final product with automated steps all in one system (importing source images, aerial triangulation, block adjustment, DEM creation, mosaicing, etc.).

Now version 5.24 has been developed, which not only processes images taken with analog and digital cameras like earlier, but also high resolution satellite, SAR space borne platforms, aerial photos of UAV (Unmanned Aerial Vehicle) and pushbroom line scanners.

UltraCam D is a metric camera, designed for precision photogrammetric applications. Vexcel Imaging $\mathrm{GmbH}$ brought the large format digital aerial camera UltraCam D onto the market in May 2003. The concept of the sensor is based on combining image data of several CCD (Charge-coupled Device) sensors and different optical systems to generate one large image. Figure 1 shows the principle

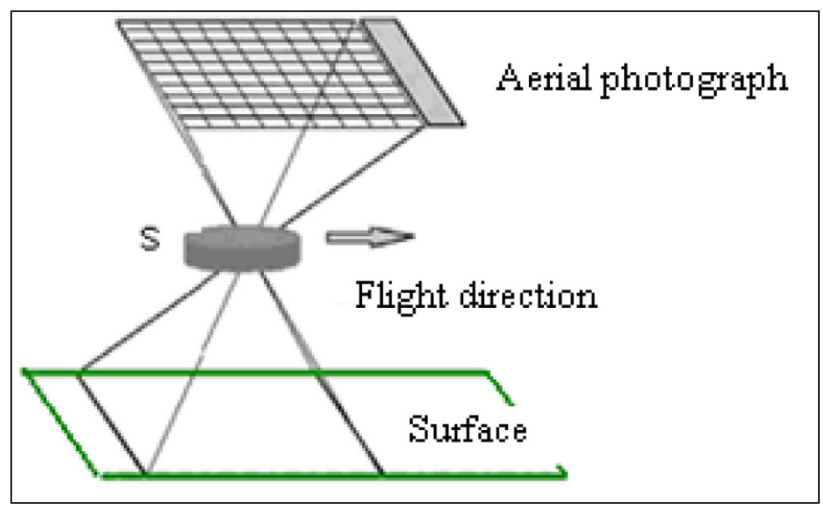

Fig. 1. Principle of the CCD-Array Camera (Dun, 2007) of a CCD-array camera. Figure shows how an aerial photo consists of pixels and how the lines of pixels are created row by row in the flight direction. An array sensor registers the ground by rows through the center $S$ of the projection (Haest et al., 2009; Dun, 2007; Krüpfl et al., 2004).

Pixels of the sensor of the UltraCam D digital camera are fixed, the objective is fixed with the focal length and thus always corresponds to a certain pixel size of square area on the ground - Ground Sampling Distance (GSD). For example, flying at 1000 meters up to the ground, the GSD is about $10 \mathrm{~cm}$. Each pixel of the sensor registers energy from with GSD defined area (Liba, 2005).

Figure 2 shows an example of aerial photographs of the railway section on the same site made by an analog and a digital camera. The aerial photo taken with the analog camera has the GSD $15 \mathrm{~cm}$. The right image segment shows the aerial photograph taken with the digital camera, which GSD is 16 $\mathrm{cm}$. Both image segments are with double-magnification and 150 pixels in diameter. Images show that the photograph taken with the digital camera is significantly clearer and objects are more distinctive, although the GSD is higher. Aerial photographs are not grainy and they have better tonality. These factors provide better interpretation with stronger aerial triangulation and mosaicing precision. (Liba, 2005; Leberl, Gruber, 2003a).

The sensor unit of UltraCam D consists of eight independent cameras, so-called cones (Fig. 3). Four of them create a large format panchromatic image. The other set of four cones is responsible for the multispectral channels of UltraCam D, i. e. red, green blue and near infrared. The panchromatic

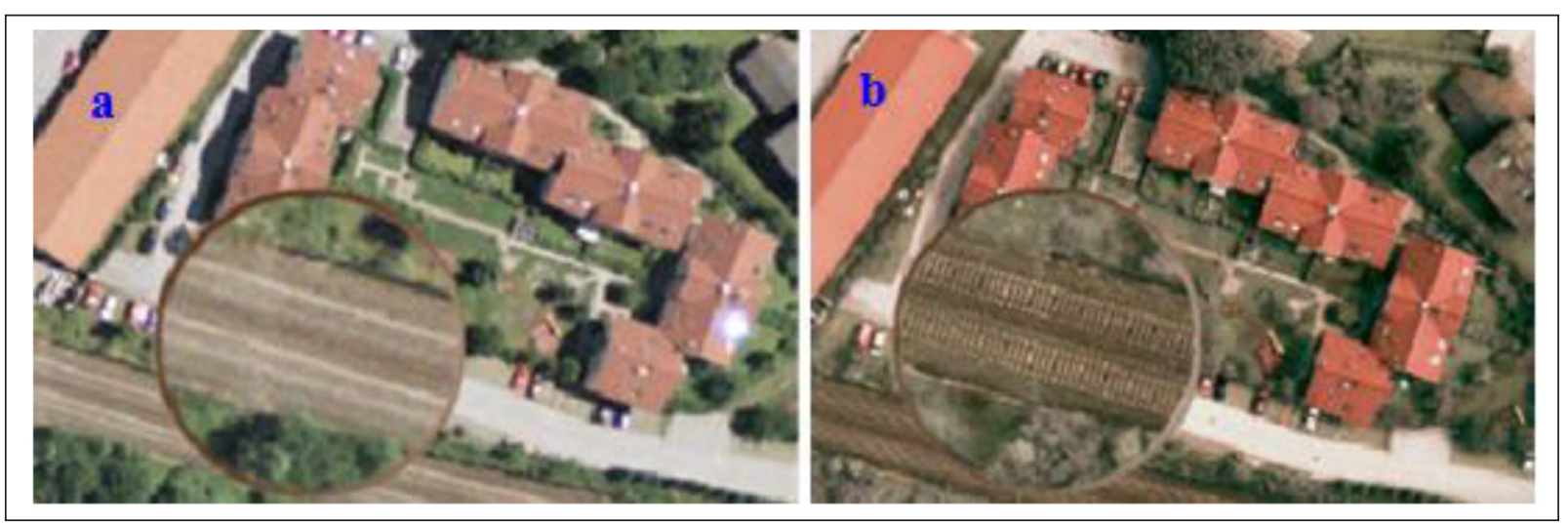

Fig. 2. a - a color image segment from the analog camera, b - an image segment from the UltraCam D digital aerial camera (Leberl, Gruber, 2003a) 


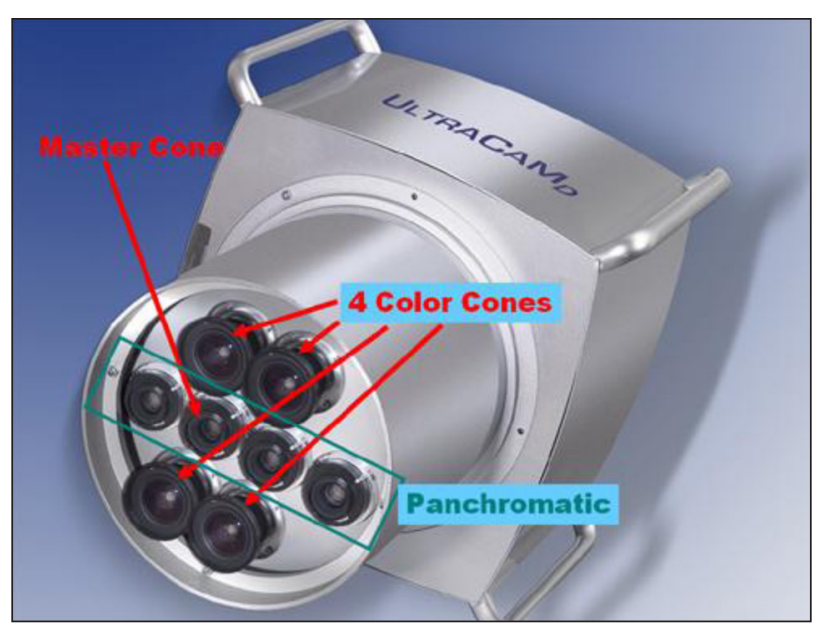

Fig. 3. UltraCam D Sensor Unit (Krüpfl et al., 2004)

image consists of 11500 pixels cross track and 7500 pixels long track, the multispectral one is simultaneously recorded at a frame size of 4000 by 2700 pixels (Krüpfl et al., 2004; Gruber et al., 2004).

Figure 4 shows that the camera unit consists of a set of eight optical cones holding a total of 13 CCD arrays to assemble a large format image in RGB and false color NIR. The panchromatic part of the camera combines a set of 9 medium format CCD sensors into a large format panchromatic image. The multi-spectral channels are supported by four additional CCD sensors. Figure 4 shows the numbered cones of panchromatic channels. By numbering the sub-images are linked together to one aerial photograph. Each of these 13 CCD sensors is the front end of a separate imaging module. It consists of the sensor, the sensor

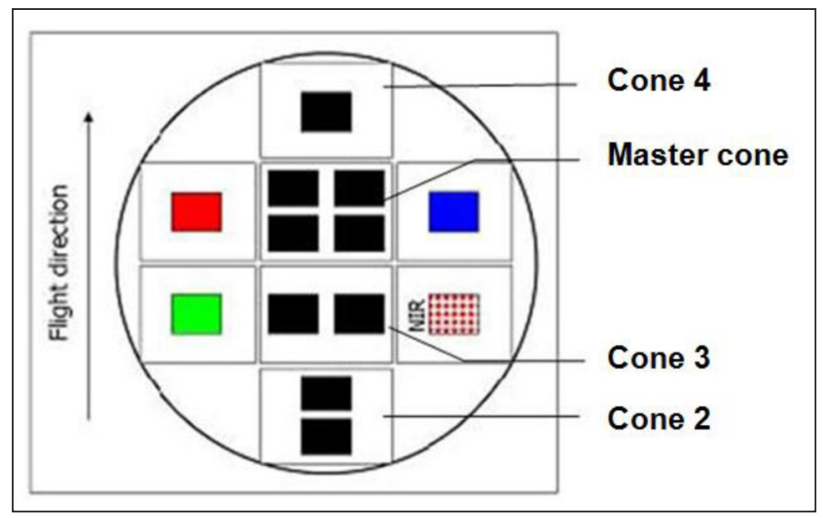

Fig. 4. The arrangements of the CCD sensors of UltraCam D (Dun, 2007) electronics, a high end analog / digital converter (ADC), a fast digital signal processor (DSP) and the IEEE 1394 data transfer unit. (Dun, 2007; Krüpfl et al., 2004).

The geometric performance of the camera is defined by the so-called "master cone", which consists of four area-based CCD-arrays in the corners of its field-of-view. The assembly of 4 CCD arrays is rigidly defined and photogrammetrically calibrated to define the image coordinate system. The four CCDs define a large format panchromatic image of the UltraCam D, while the gaps between these four sensors are filled by the other three panchromatic cones (Krüpfl et al., 2004; Dun, 2007; Leberl et al., 2003).

All panchromatic cones have the same field of view thanks to the concept of a "synoptic" imaging: the four black and white camera heads are arranged linearly along the flight direction and the aperture of the shutters is delayed (Fig. 5). A distributed parallel sensing concept offers fast frame grabbing of almost 90 Megapixel images in one second. The system is capable of imaging with time intervals of only 0.75 seconds, offering an option of very high forward overlaps. When the traditional photogrammetric workflow is based on $60 \%$ forward overlaps, then UltraCam D is able to support routine use of $80 \%$ forward overlaps in almost all circumstances. Therefore the

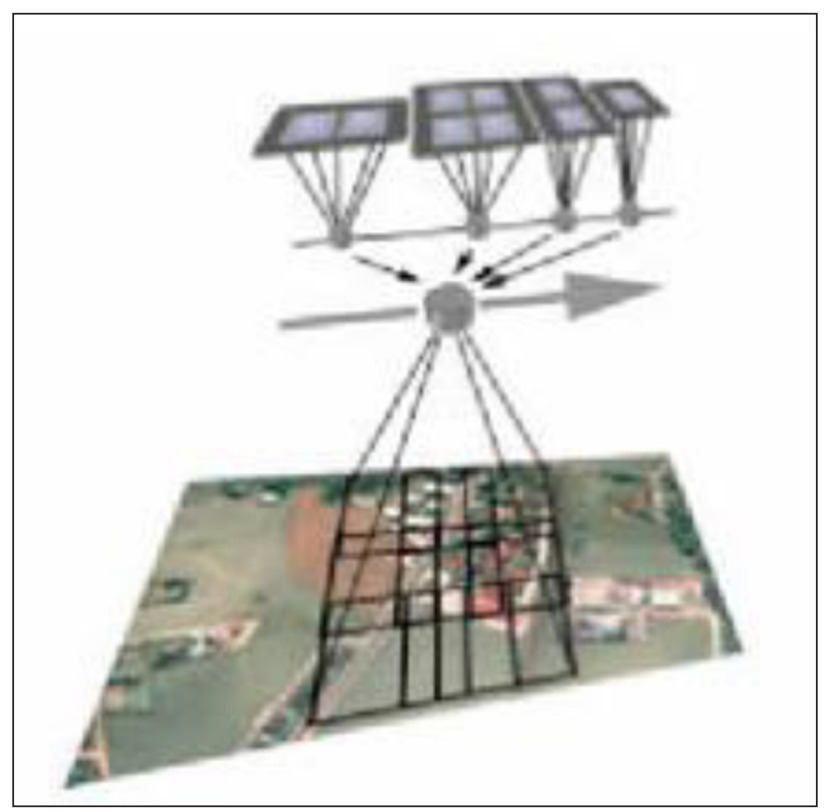

Fig. 5. Principle of spot-synchronized exposure of the four panchromatic cones of UltraCam D (Dun, 2007) 
aerial triangulation will become more robust since mismatches of tie points will disappear. DEMs will also be without mismatches and all terrain segments will have coverage (Thurgood et al., 2004; Souchon et al., 2006; Gruber et al., 2004).

Color is added to the panchromatic image in a "coloration" process. The 4 color bands (red, blue, green and NIR) are matched with the panchromatic image and then up-sampled to add 4 color values to each panchromatic pixel. The process is also denoted sometimes as "pansharpening" (Leberl, Gruber, 2003b).

\section{MATERIALS AND METHODS}

For analyzing the geometrical quality, there were 4 orthophoto mosaics made with the Photomod software, keeping in mind the possibility to use the automated and also the manual way of different processing (AT, DEM creation and mosaicing) stages. Before DEM creation, the accuracy of the block adjustment was analysed.

20 aerial photographs were used (Fig. 6), taken by the frame aerial camera UltraCam D on 7 May 2007. The area on the photographs is Tartu City.

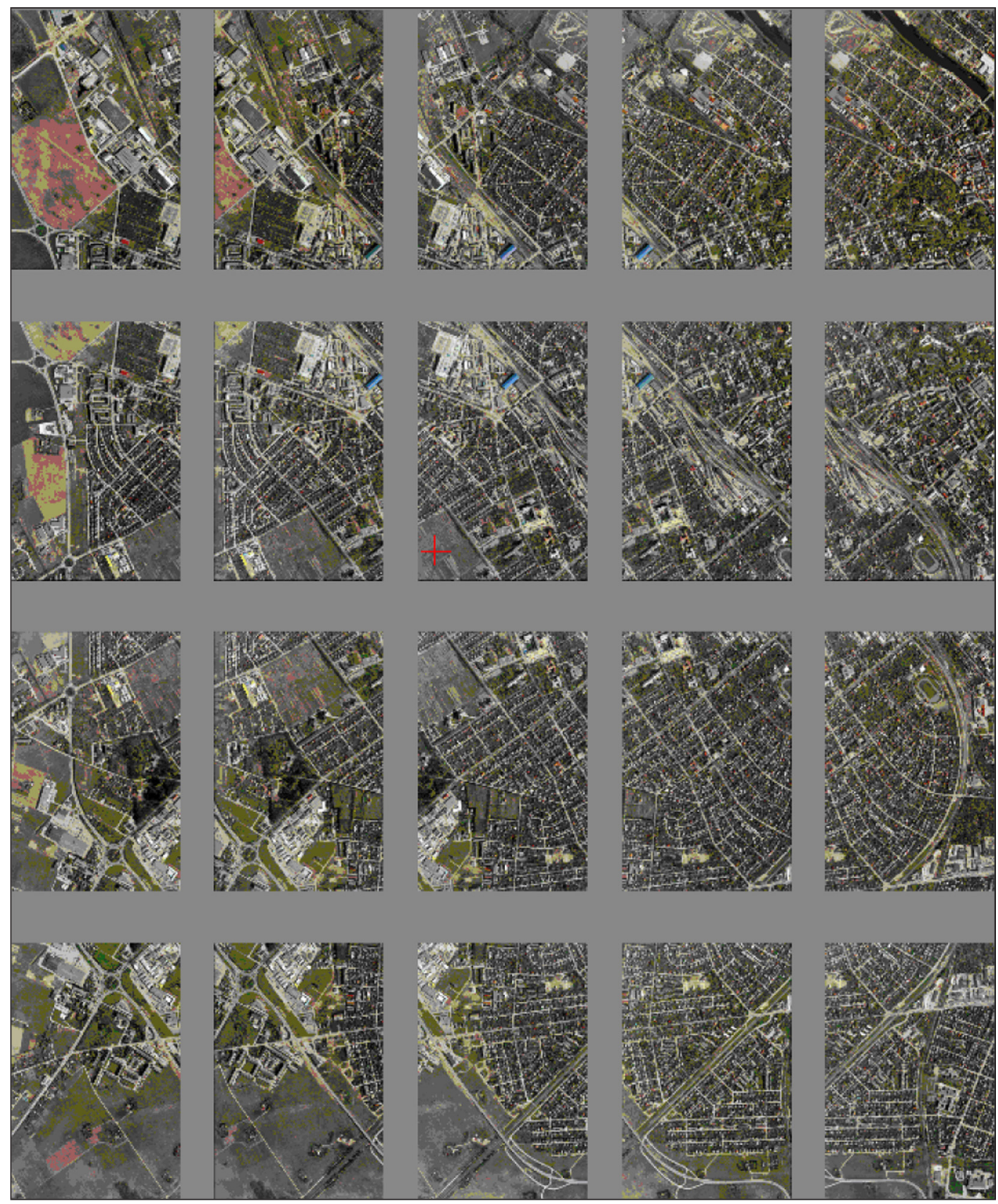

Fig. 6. Block of aerial images 
The GSD of the images is $15 \mathrm{~cm}$, the focal length $f=105.2 \mathrm{~mm}$.

The photographs were from the Estonian Land Board for study purposes.

For the ground control points in aerial triangulation and for the estimating the geometrical quality of the orthophoto mosaic, 21 points were measured. The ground control points were located in well determined places on the photographs and in well measurable places in nature, for example, the crossroads, the corners of the street crossing, etc. External orientation points were located in the corners and middle part of the block of aerial photographs in overlapping areas. Some location examples for the points are shown in Fig. 7.

The points were measured on 20-21 December 2011 by GPS Trimble 5800 in L-Est' 97 coordinate system.

Four methods to produce the orthophoto mosaics were tested in the study (Table 1):

1) Full-automatic;

2) Semi-automatic;

3) Manual;

4) Semi-manual.

The differences of the projects were in the ways of making the mosaics, depending on what stage was done automatically and what stage manually.
The projects were named according to the degree of the automation in the process. These stages are relative orientation and correcting DEM. The interior or the external orientation, block adjustment and mosaicing - these stages are automatic by inserting some parameters. In Table 1 it is shown step by step how the mosaics were made and how the mosaics differ.

The full-automatic project was the project where stages were passed through automatically without correction and the manual project was the project where stages were corrected manually. In the semiautomatic project aerial triangulation was made automatically and DEM was corrected manually. In the semi-manual project aerial triangulation was made in manual, but DEM was not corrected.

Before DEM creation, the accuracy of the block adjustment in the full-automatic and in manual projects was analyzed. The accuracy is given by residuals in coordinates, RMS (Mean Root Square Error) in xy plane and $\mathrm{z}$ plane in meters.

The RMS is calculated using Formula 1:

$$
R M S=\sqrt{2} * E_{\text {mean }},
$$

where $E_{\text {mean }}$ is the mean error calculated by using Formulas 2 and 3:

$$
E_{\text {mean }}^{x y}=\sqrt{2} * 0.5 p x l,
$$

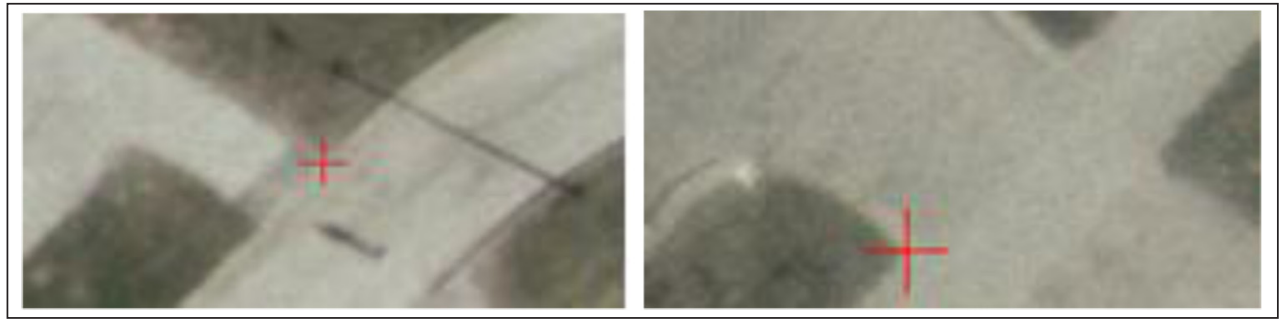

Fig. 7. Locations for points

\begin{tabular}{|c|c|c|c|c|}
\hline Project name & Project 1 & Project 2 & Project 3 & Project 4 \\
\hline Stage & Full-automatic & Semi-automatic & Manual & Semi-manual \\
\hline \multicolumn{5}{|l|}{ Aerial triangulation: } \\
\hline Interior orientation & Automatic & Automatic & Automatic & Automatic \\
\hline External orientation & Manual & Manual & Manual & Manual \\
\hline Relative orientation & Automatic & Automatic & Manual & Manual \\
\hline Block adjustment & Automatic & Automatic & Automatic & Automatic \\
\hline \multicolumn{5}{|l|}{ DTM greation } \\
\hline TIN (DEM) & Automatic & Manual & Manual & Automatic \\
\hline Mosaicing: & Automatic & Automatic & Automatic & Automatic \\
\hline
\end{tabular}

Table 1. Methods of orthophoto mosaic production 


$$
E_{\text {mean }}^{z}=f / b^{*} E_{\text {mean }}^{x y},
$$

where $E_{\text {mean }}^{x y}$ is the mean error in the $x y$ plane;

$E_{\text {mean }}^{z}$ is the mean error in the $\mathrm{z}$ plane;

$p x l=G S D$;

$f$ is the focal length;

$b$ is survey bases on the image scale (Racurs, 2012).

Tie points with big residuals were remeasured and replaced in the manual processing projects.

Geometrical quality of the orthophoto mosaics was investigated and analyzed. For the geometrical quality coordinates $(x, y)$ of 10 control points were measured on the mosaics and the coordinates were compared with GPS-coordinates. For rising the accuracy of the interactive measurements coordinates were measured in three different magnification degrees (Fig. 8). For the analyzing the mean coordinates of the three measurements were used.

For geometrical quality analyzing there were differences in the coordinates of different projects calculated from GPS-coordinates and mean coordinates in the mosaics, the dislocations and RMS-s of the mosaics which are calculated using the Gauss formula (Formula 4):

$$
m= \pm \sqrt{\frac{\Delta^{2}}{n}},
$$

where $\Delta^{2}$ is the sum of the square differences between GPS- and mosaic-coordinates;

$n$ is the number of measurements (Randjärv, 1997).

The accuracy of the self RMS was calculated using Formula 5 (Randjärv, 1997):

$$
m_{m}= \pm \frac{m}{\sqrt{2 n}}
$$

\section{RESULTS AND DISCUSSION}

In Tables 2 and 3 the maximum coordinate residuals of tie points and ground control points and RMS are given:

$X, Y, Z$ are coordinates;

$X 1, X 2, Y 1, Y 2, Z 1, Z 2$ are coordinates calculated from the model;

$X m, Y m, Z m$ are display coordinate values calculated from all models;

$\mathrm{Xg}, \mathrm{Yg}, \mathrm{Zg}$ are coordinates of ground control points.
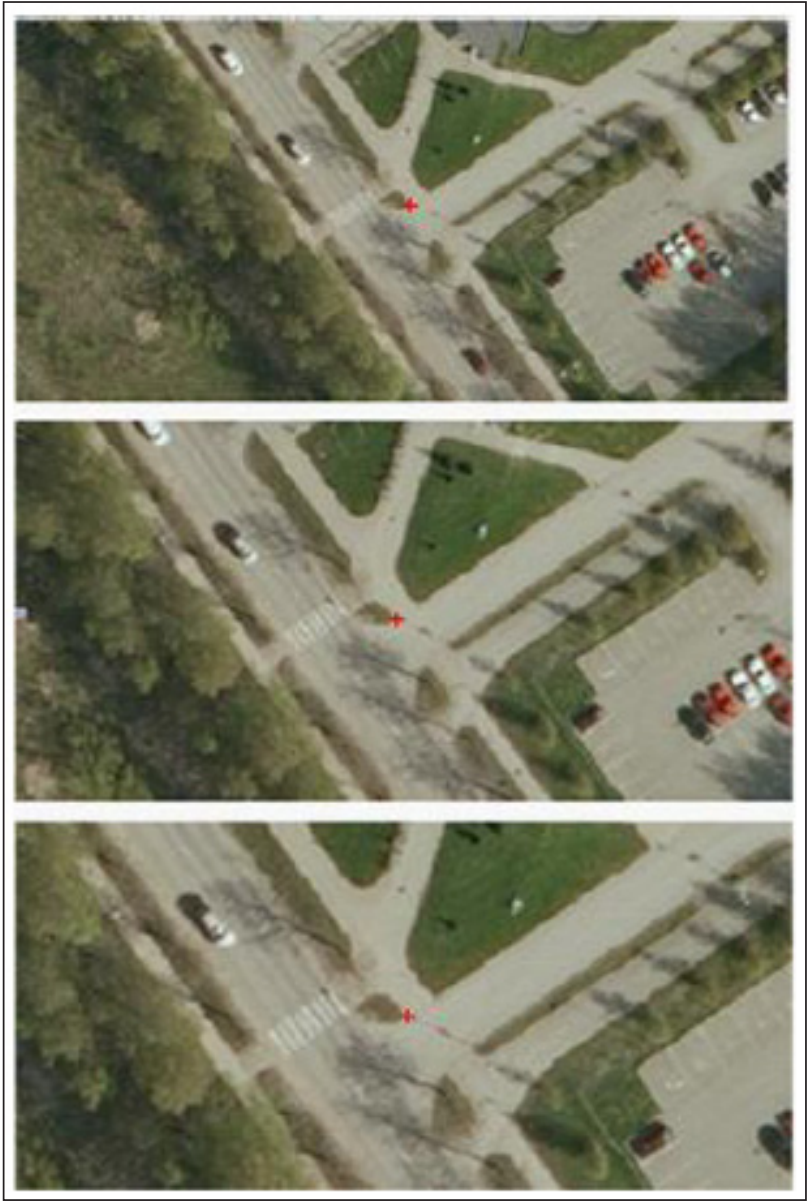

Fig. 8. Point measurements in three different magnification degrees

The permitted size was $0.2 \mathrm{~m}$ (GSD size) for each project and by ${ }^{*}$ residuals bigger than the permitted size were marked.

In tie points of the full-automatic aerial triangulation (Table 2) there were no residuals bigger than $0.2 \mathrm{~m}$. The maximum sizes of the tie points are shown between stereo pairs, inside trips and between trips. The maximum residual in X-coordinate was 0.311 meters and in Y-coordinate 0.320 meters both between stereopairs. The maximum RMS between the stereo pairs and also between trips was the same $-0.314 \mathrm{~m}$. But generally the RMS-s were in the permitted size.

From the report of manual aerial triangulation (Table 3), we can see that there are several points which are not in the permitted size. The ground control point residuals are big, the maximum residual in $\mathrm{X}$ is even $0.630 \mathrm{~m}$. But the maximum RMS in tie points $\mathrm{X}$-, $\mathrm{Y}$-coordinates are in the permitted size. 
Table 2. Extract from the report of the full-automatic aerial triangulation block adjustment (meters)

\begin{tabular}{ccccc}
\hline \multicolumn{5}{c}{ Ground control point residuals } \\
\hline N & Xm-Xg & Ym-Yg & Zm-Zg & Exy \\
\hline Limit: & $\mathbf{0 . 2 0 0}$ & $\mathbf{0 . 2 0 0}$ & $\mathbf{0 . 2 0 0}$ & $\mathbf{0 . 2 0 0}$ \\
\hline Mean absolute: & 0.022 & 0.065 & 0.000 & 0.071 \\
\hline RMS: & 0.024 & 0.069 & 0.000 & 0.073 \\
\hline Maximum: & 0.032 & 0.098 & 0.000 & 0.098 \\
\hline
\end{tabular}

\begin{tabular}{ccccc}
\hline \multicolumn{5}{c}{ Tie point residuals (between stereopairs) } \\
\hline N & Xm-Xg & Ym-Yg & Zm-Zg & Exy \\
\hline Limit: & $\mathbf{0 . 2 0 0}$ & $\mathbf{0 . 2 0 0}$ & $\mathbf{0 . 2 0 0}$ & $\mathbf{0 . 2 0 0}$ \\
\hline Mean absolute: & 0.053 & 0.018 & 0.103 & 0.059 \\
\hline RMS: & 0.076 & 0.030 & 0.128 & 0.081 \\
\hline Maximum: & $0.311^{\star}$ & $0.202^{\star}$ & $0.320^{\star}$ & $0.314^{\star}$ \\
\hline
\end{tabular}

\begin{tabular}{ccccc}
\hline \multicolumn{5}{c}{ Inside strips } \\
\hline N & Xm-Xg & Ym-Yg & Zm-Zg & Exy \\
\hline Limit: & $\mathbf{0 . 2 0 0}$ & $\mathbf{0 . 2 0 0}$ & $\mathbf{0 . 2 0 0}$ & $\mathbf{0 . 2 0 0}$ \\
\hline Mean absolute: & 0.029 & 0.003 & 0.110 & 0.030 \\
\hline RMS: & 0.039 & 0.004 & 0.133 & 0.039 \\
\hline Maximum: & 0.119 & 0.011 & $0.288^{*}$ & 0.119 \\
\hline
\end{tabular}

\begin{tabular}{ccccc}
\hline \multicolumn{5}{c}{ Between strips } \\
\hline N & Xm-Xg & Ym-Yg & Zm-Zg & Exy \\
\hline Limit: & $\mathbf{0 . 2 0 0}$ & $\mathbf{0 . 2 0 0}$ & $\mathbf{0 . 2 0 0}$ & $\mathbf{0 . 2 0 0}$ \\
\hline Mean absolute: & 0.082 & 0.035 & 0.084 & 0.094 \\
\hline RMS: & 0.106 & 0.046 & 0.110 & 0.116 \\
\hline Maximum: & $0.311^{\star}$ & $0.202^{\star}$ & $0.302^{\star}$ & $0.314^{*}$ \\
\hline
\end{tabular}

For the geometrical quality, coordinates of 10 points were measured on the orthophoto mosaics and compared with GPS-coordinates. The GPScoordinates were the correct coordinates for the quality. In Tables 4 and 5 the calculations of the geometrical quality of the mosaics are presented. The permitted size for the geometrical quality was $0.45 \mathrm{~m}$ - the triple size of the aerial photographs GSD. This kind of accuracy requirements is given by the Estonian Land Board.

In Tables 4 and 5 we can see that the dislocations in the coordinates are clearly different in the full-automatic project. The maximum dislocation in the full-automatic project was $2.937 \mathrm{~m}$ and it is 5 times bigger than the maximum of other projects. In all projects the biggest dislocations were in points 4 and 29. Both the points were located in the edges of the aerial block and therefore not so good to determine. The smallest dislocation was 0.047 in point 21 of the semimanual projects.
Table 3. Extract from the report of the manual aerial triangulation block adjustment (meters)

\begin{tabular}{|c|c|c|c|c|}
\hline \multicolumn{5}{|c|}{ Ground control point residuals } \\
\hline $\mathbf{N}$ & $\mathrm{Xm}-\mathrm{Xg}$ & Ym-Yg & $\mathrm{Zm}-\mathrm{Zg}$ & Exy \\
\hline Limit: & 0.200 & 0.200 & 0.200 & 0.200 \\
\hline 11 & $-0.292^{*}$ & 0.630 & -0.029 & $0.695^{\star}$ \\
\hline 22 & -0.077 & $-0.218^{\star}$ & -0.036 & $0.231^{\star}$ \\
\hline 5 & 0.166 & -0.118 & -0.015 & $0.204^{*}$ \\
\hline Mean absolute: & 0.123 & $0.210^{*}$ & 0.046 & $0.249^{*}$ \\
\hline RMS: & 0.146 & 0.274 & 0.055 & $0.310^{*}$ \\
\hline Maximum: & $0.292^{*}$ & $0.630^{*}$ & 0.093 & $0.695^{\star}$ \\
\hline \multicolumn{5}{|c|}{ Tie point residuals (between stereopairs) } \\
\hline $\mathbf{N}$ & $\mathrm{Xm}-\mathrm{Xg}$ & Ym-Yg & $\mathrm{Zm}-\mathrm{Zg}$ & Exy \\
\hline Limit: & 0.200 & 0.200 & 0.200 & 0.200 \\
\hline Mean absolute: & 0.053 & 0.019 & 0.108 & 0.059 \\
\hline RMS: & 0.072 & 0.027 & 0.147 & 0.077 \\
\hline Maximum: & 0.194 & 0.095 & $0.378^{\star}$ & $0.200^{\star}$ \\
\hline \multicolumn{5}{|c|}{ Inside strips } \\
\hline $\mathbf{N}$ & $\mathrm{Xm}-\mathrm{Xg}$ & Ym-Yg & $\mathrm{Zm}-\mathrm{Zg}$ & Exy \\
\hline Limit: & 0.200 & 0.200 & 0.200 & 0.200 \\
\hline Mean absolute: & 0.039 & 0.002 & 0.119 & 0.039 \\
\hline RMS: & 0.063 & 0.003 & 0.170 & 0.063 \\
\hline Maximum: & 0.172 & 0.008 & $0.374^{\star}$ & 0.172 \\
\hline \multicolumn{5}{|c|}{ Between strips } \\
\hline $\mathbf{N}$ & Xm-Xg & Ym-Yg & $\mathrm{Zm}-\mathrm{Zg}$ & Exy \\
\hline Limit: & 0.200 & 0.200 & 0.200 & 0.200 \\
\hline Mean absolute: & 0.059 & 0.027 & 0.085 & 0.070 \\
\hline RMS: & 0.072 & 0.035 & 0.103 & 0.080 \\
\hline Maximum: & 0.158 & 0.095 & $0.204^{\star}$ & 0.158 \\
\hline
\end{tabular}

The mean dislocation was smallest in the manual project $-0.262 \mathrm{~m}$. The dislocations in semimanual and semi-automatic projects were $0.277 \mathrm{~m}$ and $0.3 \mathrm{~m}$, respectively. The biggest mean value was in the automatic projects where the dislocation was up to 4 times bigger than the mean values of other project.

Fig. 9 presents graphically the RMSs of the mosaics.

Like dislocations, also the RMS of the automatic project mosaics is big $-1.805 \mathrm{~m}$, which crosses the limit for 4 times. But this kind of a big value is obvious, there is no improvement in aerial triangulations and no DEM corrections made. The correction accuracy of aerial triangulation (like the semi-manual project) and DEM corrections (semi-automatic project) improves the results, the RMSs are $0.335 \mathrm{~m}$ and $0.324 \mathrm{~m}$, respectively. We can get the best results from the manual project - the RMS is $0.308 \mathrm{~m}$ but for that aerial triangulation and DEM corrections have to be made. 


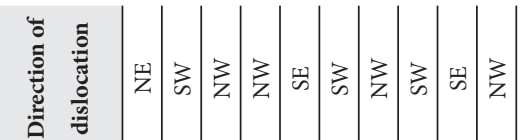

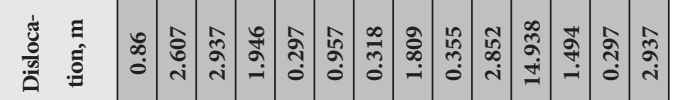

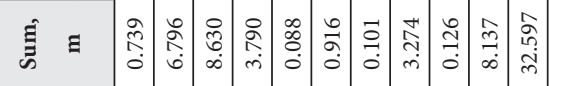

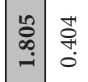

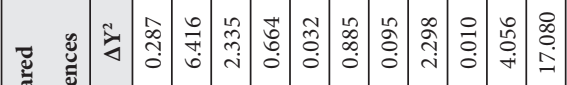

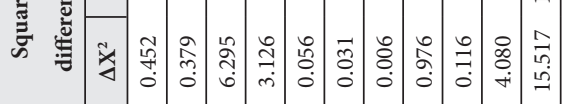

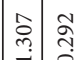

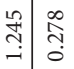

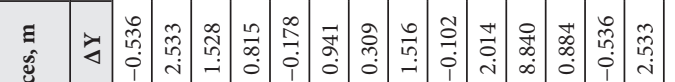

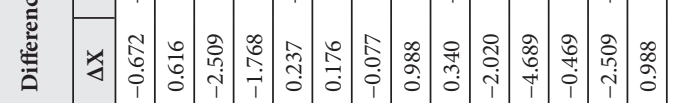

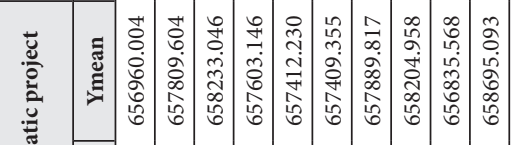

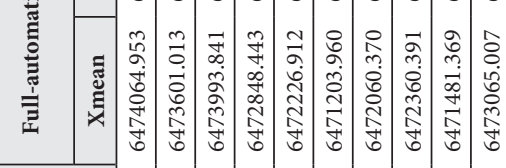

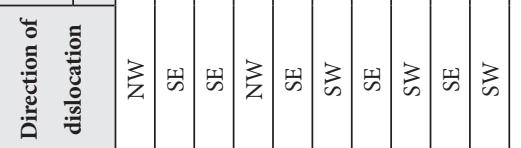

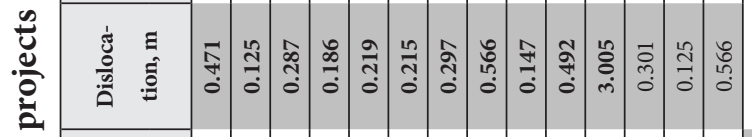

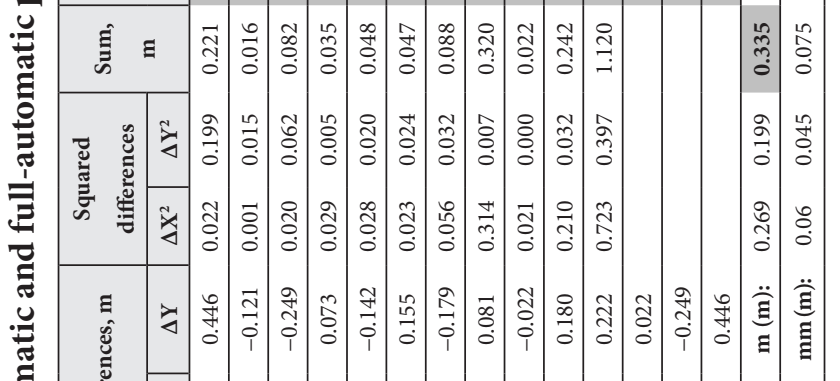

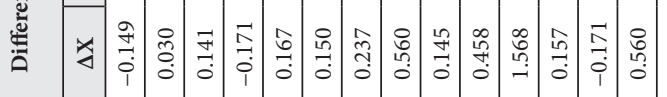

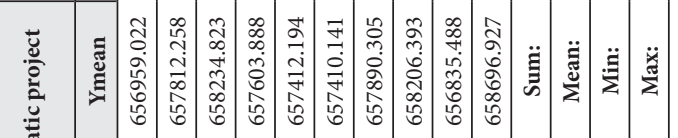

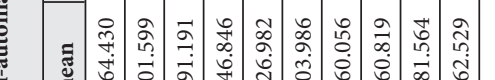

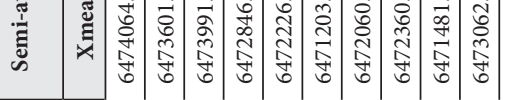

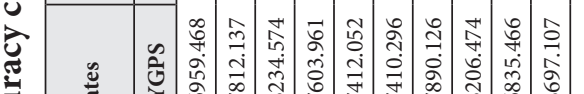

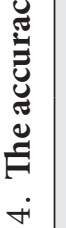

$\frac{0}{0}$

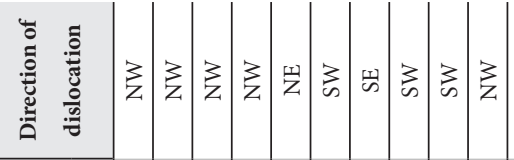

旁

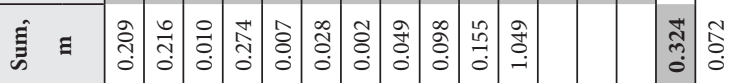

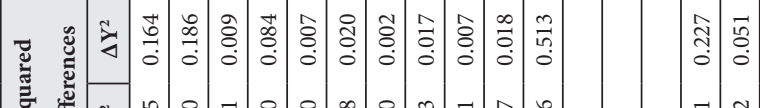

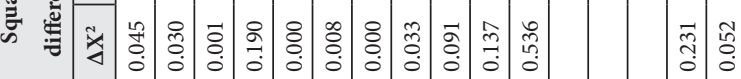

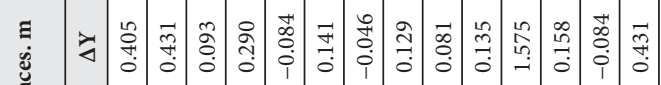

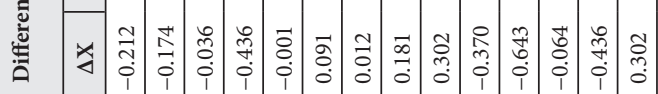

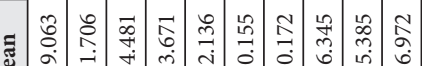

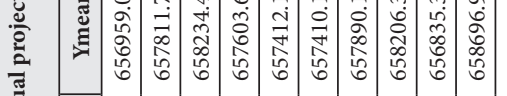

可

至

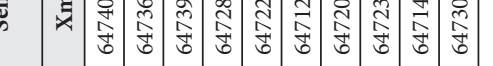

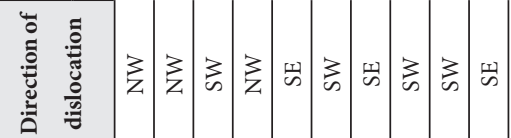

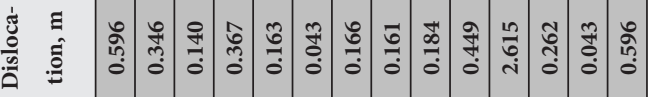

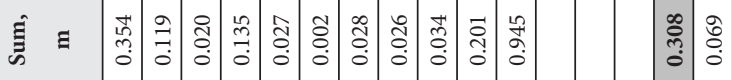

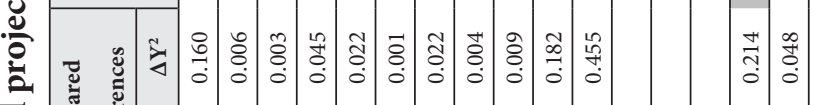

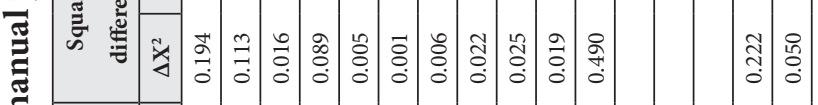

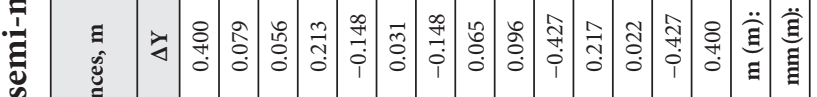

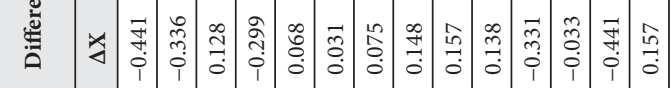

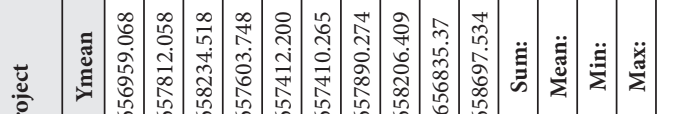

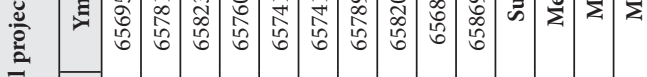

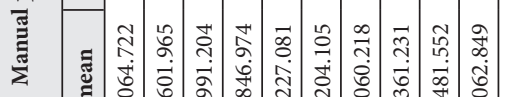

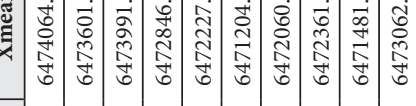

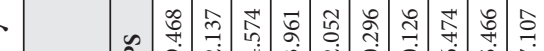

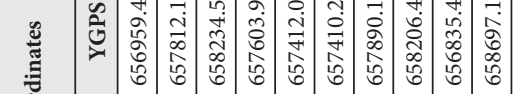

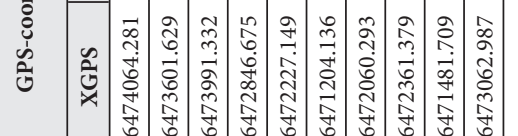

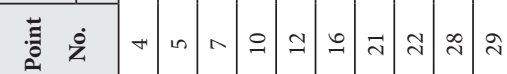




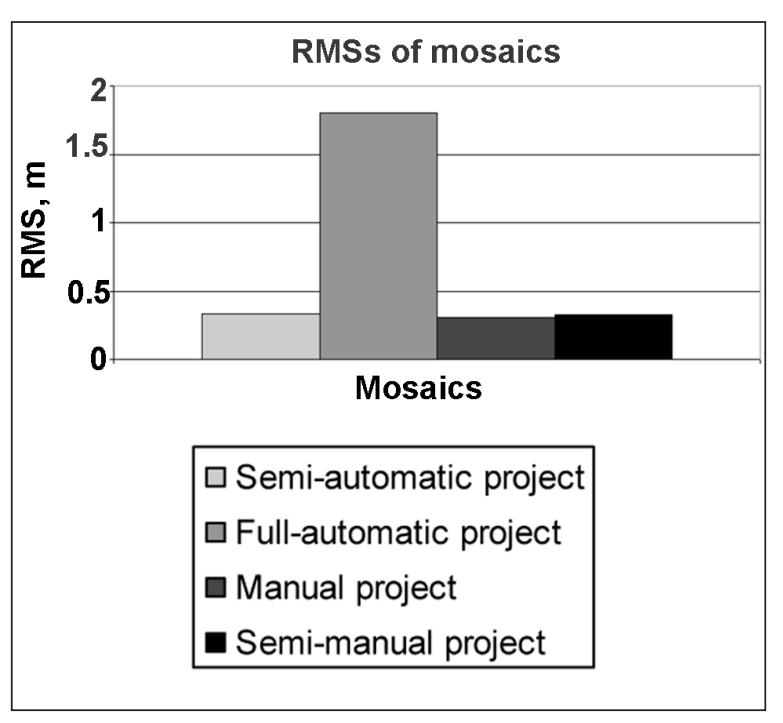

Fig. 9. RMSs of the mosaics

\section{CONCLUSIONS}

Three methods of orthophoto mosaic productions using UltraCam D images and photogrammetric software Photomod out of four resulted in acceptable quality $(0.45 \mathrm{~m})$. The RMS of the most geometrically accurate mosaic was $0.308 \mathrm{~m}$, which is calculated in turn with the error $0.069 \mathrm{~m}$ and which was in the manual project. From the results we can conclude that the full-automatic approach resulted in unacceptable geometric accuracy - the RMS was $1.805 \mathrm{~m}$. Also, the dislocations were big in the full-automatic project.

From manual aerial triangulation we can get the accurate X-, Y-coordinates even if the DEM is not corrected. The DEM has to be corrected when the aerial triangulation is made automatically.

Received 20 April 2013 Accepted 17 June 2013

\section{REFERENCES}

1. Dun W. 2007. Geometric Aspects of Large Size Digital Frame Cameras and Their Use for Photogrammetric Data Acquisition. Hannover, Germany [cited 2012-02-05]. Available from internet: http://www.ipi.uni-hannover.de/fileadmin/ institut/pdf/Wu_Diplomarbeit.pdf
2. Gruber M., Perko R., Ponticelli M. 2004. The All Digital Photogrammetric Workflow: Redundancy and Robustness. Proceedings of ISPRS Congress 2004. Istanbul, Turkey [cited 2012-01-24]. Available from internet: http://www.isprs.org/proceedings/XXXV/congress/comm1/papers/43.pdf

3. Haest B., Biesemans J., Horsten W., Everaerts J. 2009. Radiometric Calibration of Digital Photogrammetric Camera Image Data. ASPRS 2009 Annual Conference Proceedings. Baltimore, Maryland [cited 2012-02-05]. Available from internet: http://publications.vgt.vito.be/documents/ BH/Haest_2009_ASPRS\%20Proceedings $\% 20$ Baltimore\%20USA_adj.pdf

4. Krüpfl M., Kruck E., Gruber M. 2004. Geometric Calibration of the Digital Large Format Aerial Camera UltraCamD. Proceedings of ISPRS Congress 2004. Istanbul, Turkey [cited 2012-01-24]. Available from internet: http://www.isprs.org/proceedings/ $\mathrm{XXXV/congress/comm1/papers/8.pdf}$

5. a) Leberl F., Gruber M. 2003. Economical large format aerial digital camera. GIM International [cited 2012-02-05]. Available from internet: http:// ve000022.host.inode.at/downloads/paper-UCDGIM-june2003.pdf

6. b) Leberl F., Gruber M. 2003. Flying the New Large Format Digital Aerial Camera Ultracam. Stuttgart, Germany [cited 2012-02-05]. Available from internet: http://www.ifp.unistuttgart.de/publications/ phowo03/gruber.pdf

7. Leberl F., Gruber M., Ponticelli, Bernoegger S., Perko R. 2003. The Ultracam Large Format Aerial Digital Camera System. Proceedings of The American Society For Photogrammetry \& Remote Sensing. Anchorage, Alaska [cited 2012-01-05]. Available from internet: http://vicos.fri.uni-lj.si/ data/publications/leberl03the.pdf

8. Liba N. 2005. Fotogramm-meetria alused. Tartu: Eesti Põllumajandusülikool. 303 p.

9. Racurs. 2012. Accuracy Control at Various Stages of Photogrammetric Processing in PHOTOMOD System. Moscow, Russia [cited 2013-03-15]. Available from internet: http://www.racurs.ru/ www_download/articles/Accuracy_eng.pdf

10. Randjärv J. 1997. Geodeesia I osa. Tartu. 360 p.

11. Souchon J. P., Paparoditis N., Martin O., Meynard C., Thom C. 2006. Is There an Ideal Digital Aerial Camera? Paris, France [cited 2012-02-05]. Available from internet: http://www.isprs.org/proceedings/XXXVI/part1/Papers/PS3-45.pdf

12. Thurgood J. D., Gruber M., Karner K. 2004. Multiray Matching for Automated 3D Object Modeling. Istanbul, Turkey [cited 2012-02-05]. Available from internet: http://www.isprs.org/proceedings/ xxxv/congress/comm3/papers/256.pdf 
Natalja Liba, Ina Järve, Marian Rand

ORTOFOTOMOZAIKOS KOKYBE் TAIKANT

IVAIRIAIS METODAIS PARINKTUS VAIZDUS

Santrauka

Fotogrametrijos produktai, ypač ortofotografijos, modernios technikos vystymosi laikotarpiu tapo vertinga erdvinių duomenų bazių dalimi. Didejja detalių, geresnès rezoliucijos nuotraukų poreikis, ieškoma galimybių labai greitai daryti itin tikslias nuotraukas. Fotogrametrijos kompiuterinès programos, naudojamos gaminant ortofotografijas, igalina automatizuotai gauti kelias ortofotografijos fazes. Kiekviena ši fazè turi poveiki galutiniam produktui. Kyla klausimas - kiek reikia vartoti kompiuterinès programos automatizuotų fazių, kad sukurtume naudotoją tenkinančios kokybès skaitmeninę ortofotografiją?

Ieškant atsakymo skirtingais metodais buvo pagamintos 4 ortofotomozaikos (automatizuoto ir rankinio valdymo). Šios nuotraukos buvo darytos skaitmenine UltraCam D telekamera vartojant fotogrametrijos kompiuterinę programą 5.1, pagamintą Rusijoje. Kiekvienos mozaikos geometrinè kokybė tikrinta matuojant atstumą tarp kontrolinių taškų ant žemès ir gautose ortofotomozaikose. RMS tikslumas - iki 0,45 m. Trijų ortofotomozaikų tikslumas buvo precizinis. Daugumos mozaikų geometrinis tikslumas RMS buvo 0,308 m (skaičiavimo paklaida $0,069 \mathrm{~m}$; šios paklaidos rastos taikant rankini prietaisų valdymą). Tačiau visai automatizuotas aparatūros valdymas netenkino matavimo rezultatų tikslumo: RMS buvo 1,805 m.

Raktažodžiai: aviacine trianguliacija, skaitmeninis aukščio modelis (DEM), geometrinis tikslumas, GSD, ortofotomozaika, UltraCam D 